\title{
Borassus aethiopum Mart. (Arecaceae) in Limpopo province with a key to South African palms
}

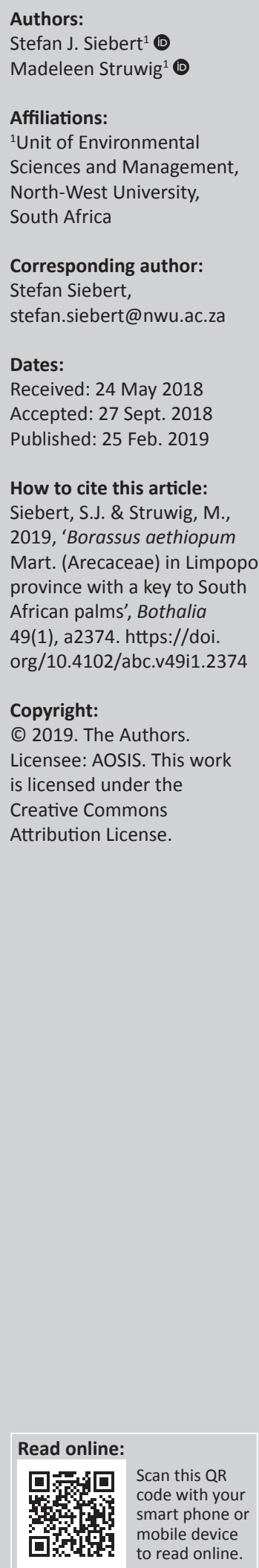

Background: Borassus aethiopum Mart. commonly occurs in many parts of tropical Africa, and in South Africa it is restricted to the Leydsdorp region where it is conspicuous along the Selati River. The species is sometimes considered to have been introduced to South Africa because of its disjunct distribution. It has remained poorly studied and little is known about the local populations of this palm.

Objectives: This study provides a descriptive treatment and documents the population structure of B. aethiopum in this area, and presents a key to the six indigenous palm species of South Africa.

Method: All accessible populations were surveyed and documented, and eight transects were randomly placed to gather data on size-class distributions. Borassus aethiopum and other indigenous palm species were compared morphologically.

Results: The population structure analyses of B. aethiopum revealed a monotonic decline, but the permutation index suggested that the species is prone to recruitment events. This is supported by patches that are dominated by specific height classes. Leaf shape and size, fruit size and geographical distribution were the diagnostic characters most useful to recognise the species of South African indigenous palms.

Conclusion: Borassus aethiopum is distinguishable from other South African palms based on stem, leaf and fruit characters. It is considered as indigenous to Granite Lowveld as the palm is part of the natural vegetation and is characterised by a size-class distribution reflecting a stable population.

\section{Introduction}

The Flora of Southern Africa (FSA) comprises more than 30000 plant species with $60 \%$ endemism (Van Wyk \& Smith 2001). Despite this diversity, palms are poorly represented in South Africa, with only six indigenous species. Two species are endemic: Jubaeopsis caffra Becc. (monotypic genus), which is endangered and restricted to coastal Pondoland (Hurter et al. 2007), and Raphia australis Oberm. \& Strey, which is considered vulnerable and restricted to the Maputaland coastline from just south of Kosi Bay to $50 \mathrm{~km}$ north of Maputo in Mozambique (Matimele et al. 2016). The other four species are widespread in parts of Africa: Borassus aethiopum Mart., Hyphaene coriacea Gaertn., H. petersiana Klotzsch ex Mart. and Phoenix reclinata Jacq. (Klopper et al. 2006). Approximately 320 exotic palm species are cultivated in South Africa (Glen 2002) and it has been found that some of these species, such as Livistona chinensis R.Br., have become naturalised (Siebert, Zobolo \& Dowe 2010).

Amongst the taxonomic treatments of South African palms were those in 'Flora Capensis' (Wright 1897) and a book on the indigenous palms of southern Africa (Wicht 1969). The only recent treatment including some of the South African Arecaceae was in Flora Zambesiaca (Dransfield 2010). This included B. aethiopum, that is one of three Borassus species that are found in Africa and Madagascar (five worldwide). The other two African species are B. akeassii Bayton, Ouédraogo \& Guinko and B. madagascariensis (Jumelle \& Perrier) Bojer ex Jumelle \& Perrier (Bayton 2007).

The first mention of B. aethiopum occurring in Limpopo (Northern Transvaal), South Africa, was made by Hutchinson and Dalziel (1936). It has often been debated whether B. aethiopum in South Africa occurred here naturally or was introduced (Schmidt, Lotter \& McCleland 2007). It was reported by Burtt Davy (of the then Transvaal Department of Agriculture) that a couple of trees of an original grove of about 50 remained at Sutherland Reef Mine near Leydsdorp in 1906 (Dyer 1952). Dyer speculated that B. aethiopum was introduced in the latter part of the $1800 \mathrm{~s}$ based on the population structure, which was dominated by a colony of young plants and only a few mature individuals. He later provided evidence to the contrary when he reported on observations made by a certain 
Mr Heinrich Altenroxal of the Thabena Farming Association that adult plants were used extensively for mine timbers which could have depleted the populations. Present thought recognises B. aethiopum as an indigenous species of South Africa (Bayton 2007).

Research on South African palms has generally been very limited, and the uncertainty regarding the origin of B. aethiopum has left it rather unobserved as no previous research has been conducted to understand the population in South Africa. The palm is a common feature of the landscape along the Selati River in South Africa and this study aims to determine the size and structure of the population, provide a detailed species description and construct a key to distinguish it from other palms indigenous to South Africa.

\section{Material and methods}

Distribution records were obtained from the National Herbarium in Pretoria (PRE) and A.P. Goossens Herbarium (PUC). Further locality records were obtained from field visits in October 2016 and 31 points were logged (Figure 1a). At each point, all the plants in a 100 m radius were recorded, which varied between 1 and 64 individuals. Plants were classified as sub-juveniles (no stem; $<1 \mathrm{~m}$ tall), juveniles (no flowers or fruit; leaf bases still attached to stem; $1 \mathrm{~m}-8 \mathrm{~m}$ ) and mature plants (flowers or fruit present; leaf bases have been shed and there is a swelling on the stem; $8 \mathrm{~m}-12 \mathrm{~m}$ tall). Binoculars were used to determine whether palms were male or female. These census data allowed for the construction of a distribution map and to characterise the population. Data were also collected regarding the number of inflorescences per female plant and fruits per female plant.

Eight transects of $100 \mathrm{~m}$ were randomly placed. Plants up to $4 \mathrm{~m}$ height were measured with a measuring stick and those with heights above $4 \mathrm{~m}$ were determined by using a clinometer. Height class distributions were compiled. Sturge's rule was applied to determine the size-class distribution and frequency intervals for the population graphs (Scott 2009). Stability between successive size classes was determined using quotient analysis; likelihood that any two trees within a population originate from the same size class was assessed by Simpson's Index of Dominance (SDI) and Permutation Index (PI) was calculated for the population to calculate the degree of deviation from a monotonic decline or from an inverse-J curve (Siebert et al. 2018).

\section{Results and discussion}

\section{Taxonomic treatment}

Borassus aethiopum Mart., Hist. Nat. Palm. 3: 220. (1838); Borassus flabellifer L. var. aethiopum (Mart.) Warb. in

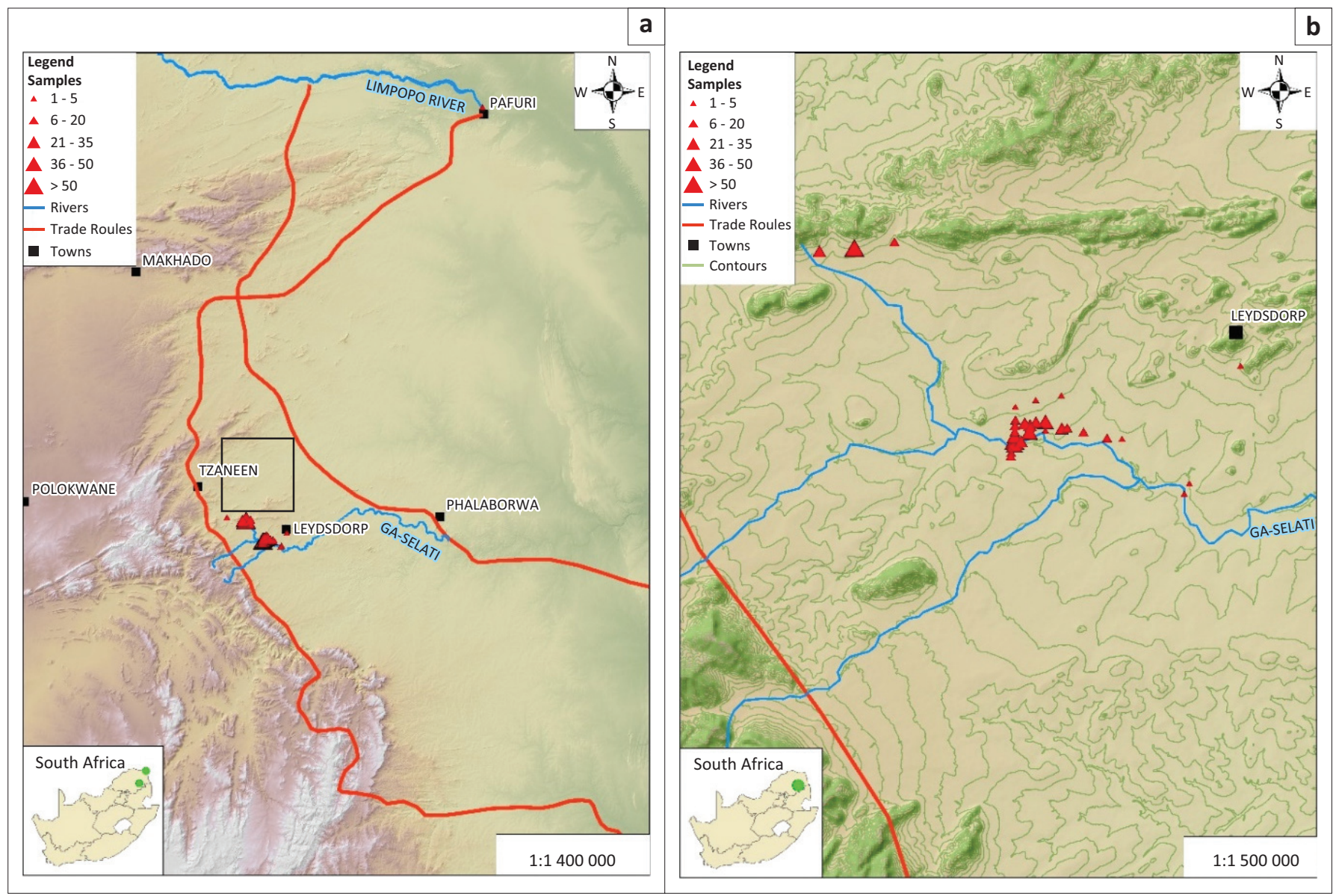

Source: S. van Eeden, Geography and Environmental Management, North-West University

FIGURE 1: (a) Distribution of Borassus aethiopum in South Africa (from Pafuri to Leydsdorp) based on herbarium specimens and field observations. Major trade routes are indicated in red and are based on De Vaal (1984). (b) Distribution of clumps along the Selati River. Clump sizes are accounted for under sample size intervals. 
Pflanzenw. Ost-Afrikas B: 20 (1895). Type: Ghana, Weija, 24

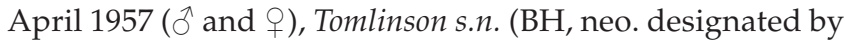
Bayton 2007).

Borassus sambiranensis Jum. \& H. Perrier, Ann. Mus. Colon. Marseille sér. 3, 1: 67 (1913). Type: Madagascar, Antsiranana province, Ambanja, 28 March 2003 ( $(\hat{)})$, Bayton $\mathcal{E}$ Ranaivojaona 55 (K-000300224, neo. designated by Bayton 2007).

Borassus deleb Becc., Webbia iv: 339 (1914). Type: Sudan, unknown locality and date ()), Salvago Raggi, s.n. (FI, holo.).

\section{Description}

Stems solitary, $20 \mathrm{~m}-25 \mathrm{~m}$ tall, straight, with conspicuous swelling half way up the stem (Figure 2a), up to $80 \mathrm{~cm}$ in diameter; dioecious; young palms covered with dry leaf sheaths (Figure $2 b$ ). Leaves 18-27 in the crown, palmate lamina up to $190 \mathrm{~cm}$ long, $1 \mathrm{~m}-3 \mathrm{~m}$ wide, coriaceous, bluish-green; petiole and sheath $130 \mathrm{~cm}-220 \mathrm{~cm}$ long, petiole $3.2 \mathrm{~cm}-9.0 \mathrm{~cm}$ wide, with large, recurved teeth on the margin extending along the margin of the first segment, teeth $0.4 \mathrm{~cm}-2.8 \mathrm{~cm}$ long; yellow-orange in distal portion becoming black towards trunk, petiole of immature leaf completely black; costa $80 \mathrm{~cm}-170 \mathrm{~cm}$ long; adaxial hastula up to $2.9 \mathrm{~cm}$ high, abaxial hastula rudimentary; segments $86 \mathrm{~cm}-120 \mathrm{~cm}, 4.7 \mathrm{~cm}-11.0 \mathrm{~cm}$ wide, linear, margin entire or splitting longitudinally in older leaves, apex acute; shortest segments $45 \mathrm{~cm}-92 \mathrm{~cm}$ long, leaf divided to $58 \mathrm{~cm}-92 \mathrm{~cm}$; commissural veins $8-15$ per $\mathrm{cm}$; dense indumentum on the ribs on some of the immature leaves. Male inflorescence branched to two orders, upper subtending branches terminating in 1-3 rachillae; rachillae green-brown and catkin-like, flowering part $37 \mathrm{~cm}-50 \mathrm{~cm}$ long, $2.3 \mathrm{~cm}-3.8 \mathrm{~cm}$ in diameter, sometimes with mamilliform apex; rachilla bracts form pits containing a cincinnus of 8-14 male flowers. Male flowers $0.2 \mathrm{~cm}-0.7 \mathrm{~cm}$ long, exserted individually from the pits, subtending bracteoles $0.8 \mathrm{~cm} \times 0.5 \mathrm{~cm}$, calyx $0.4 \mathrm{~cm} \times 0.2 \mathrm{~cm}$, shallowly divided into three sepals; three petals $0.15 \mathrm{~cm} \times 0.10 \mathrm{~cm}$; stamens 6; filaments $0.02 \mathrm{~cm} \times 0.04 \mathrm{~cm}$; anthers $0.02 \mathrm{~cm} \times 0.05 \mathrm{~cm}$, pistillode minute; ovary vestigial. Female inflorescence spicate, flowering part $36 \mathrm{~cm}-160 \mathrm{~cm}$ long, 10-28 flowers arranged in spirals. Female flowers $3 \mathrm{~cm} \times 3 \mathrm{~cm}$, bracteoles $2 \mathrm{~cm}$ in diameter, overlapping sepals $1.5 \mathrm{~cm} \times 2.0 \mathrm{~cm}$; inrolled petals $1.0 \mathrm{~cm} \times 1.5 \mathrm{~cm}$, three stigmas, ovary globose; six vestigial stamens. Fruits large drupes (Figure 2c), $7 \mathrm{~cm}-18 \mathrm{~cm} \times 7 \mathrm{~cm}-12 \mathrm{~cm}$, ovoid, flattened at apex, mesocarp fragrant, yellow to orange brown at maturity (Figure 2d), perianth segments persist, pyrenes $1 \mathrm{~cm}-3 \mathrm{~cm}$, $6.4 \mathrm{~cm}-10.9 \mathrm{~cm} \times 4.2 \mathrm{~cm}-5.7 \mathrm{~cm}$, somewhat bilobed, some with one or two external longitudinal furrows. Description based on Bayton (2007) and the specimens examined.

\section{Etymology}

Borassus is the Greek name for the immature female spadix of the date palm, and aethiopum indicates that the species occurs in Africa south of Egypt (Schmidt et al. 2007). Common names used for the tree in South Africa include Borassus Palm, Selati Palm, African Fan Palm, Borassuspalm (Afrikaans), Mopalamo (Northern Sotho).

\section{Uses}

The palm has varied uses in Africa (Ali et al. 2010). In the Khangela village and surrounding settlements near Tzaneen where the palm is cultivated, people indicated that they consume the fruit and that the palm is mainly cultivated for its cultural significance. It is believed that the spirit of Chief Magoeba, the last chief of the Batlou tribe, was housed in the stem swelling of a prominent specimen near Leydsdorp (Esterhuyse, Von Breitenbach \& Sohnge 2001).

\section{Distribution}

The palm is distributed along floodplains on sandy, welldrained alluvial soils of the Selati River near Leydsdorp in Limpopo province (Figure 1b) and along the Limpopo River at Crooks Corner near Pafuri in the Kruger National Park (Figure 1a). From here, it extended northwards into Zimbabwe, Mozambique and Zambia, and up into parts
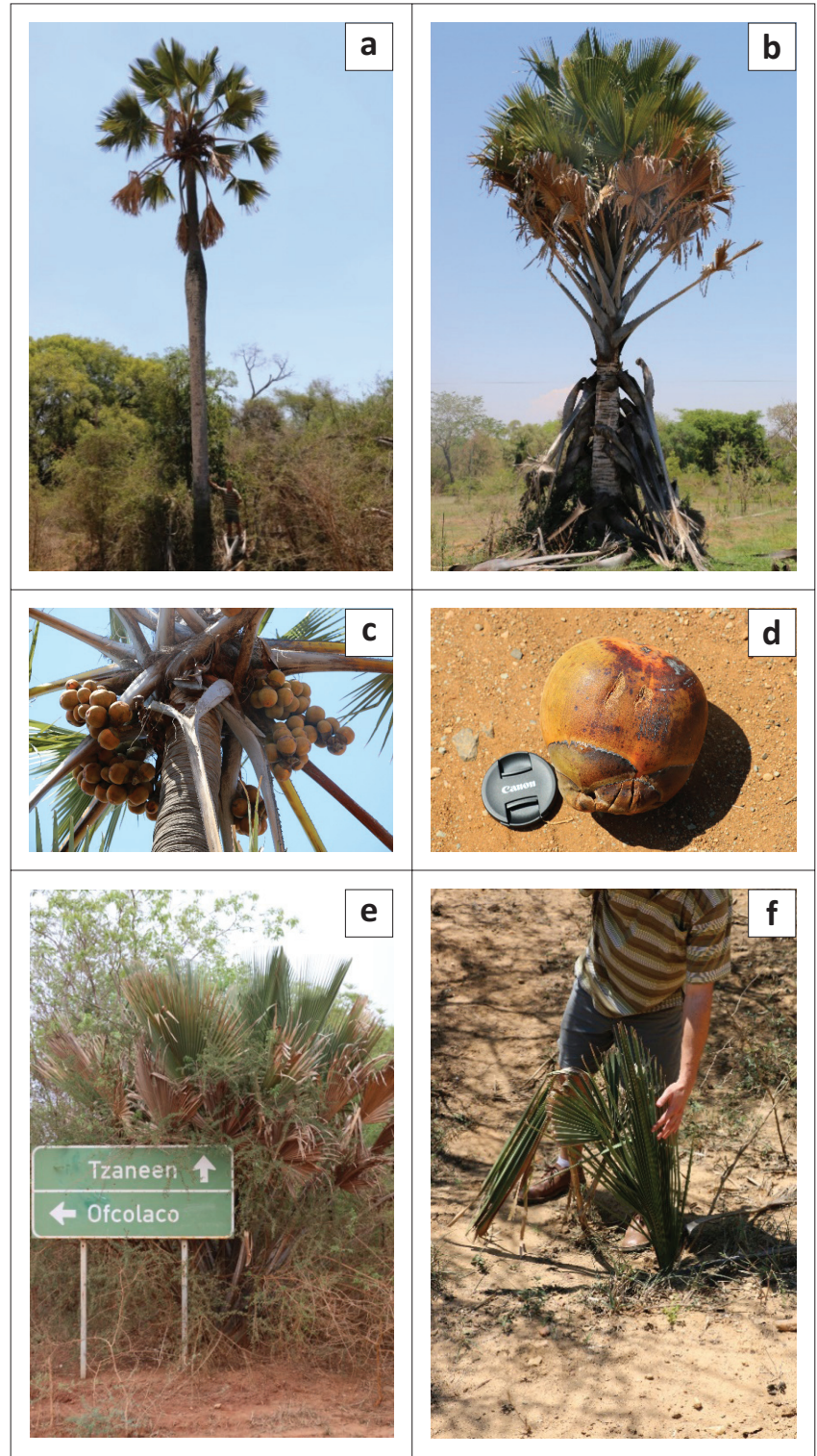

Source: Photos taken by S.J. Siebert

FIGURE 2: Borassus aethiopum. (a) A 12-m-tall reproductive specimen with swelling on the stem. (b) Specimen nearing maturity ( $8 \mathrm{~m}$ tall) and shedding leaf sheaths. (c) Female plant with ripe orange fruit. (d) Fruit. (e) Juvenile, Cloete \& Siebert 2. (f) Sub-juvenile. 
of tropical Africa (Bayton 2007; Dransfield 2010). In Limpopo, the palm is only found in the Lowveld Bioregion, with the small population in the Kruger National Park occurring in Lowveld Riverine Forest and the Leydsdorp populations associated with Granite Lowveld (Mucina \& Rutherford 2006).

\section{Phenology}

Flowers and fruits are produced throughout the year (Orwa et al. 2009). Our survey of 18 flowering female plants revealed that the number of inflorescences per plant is 2-4 per flowering event. Fruiting plants carried a mean of $20 \pm 9$ fruits per spike (Figure 2c).

\section{Maturity}

Field observations confirmed the findings of Dyer (1952) regarding the shedding of all leaf bases at more or less the same time from the stem (Figure $2 b$ ). The remarkable swelling of the stem (Figure 2a) at a certain post-juvenile stage seems to be connected in some way with the attainment of reproductive maturity, as individuals that lack the swelling were never recorded to carry any flowers or fruits. Dalziel (1937) reported that the swelling of the stem appears at about 50 years and according to Coates Palgrave (2002), it happens at $30-40$ years.

Mature plants in the Leydsdorp area drop their leaf bases at approximately $8 \mathrm{~m}$ height $(7 \mathrm{~m}$ according to Coates Palgrave [2002]), form a swelling on the trunk and then flower for the first time. We estimate the age of maturity for these specimens at approximately 47-53 years, which is in accordance with Dalziel (1937), taking into consideration the establishment years of the seedling and assuming that growth is constant throughout the palm's life. Our estimate was based on the growth rate of a single, known roadside palm (Cloete E Siebert 2) that grew $4.5 \mathrm{~m}$ in 30 years, which equated to approximately $15 \mathrm{~cm}$ per year. However, these predictions of reproductive age are much less than the matrix model prediction (on average 114 years) made by Barot et al. (2000).

\section{Dispersal}

It is generally accepted that the fruits are eaten by elephants and in this way, the seeds are distributed (Orwa et al. 2009; Zona \& Henderson 1989). It makes sense that fruit could have easily been dispersed by elephant from Zimbabwe to Pafuri (Kruger National Park) in South Africa across the Limpopo River (Figure 1). However, considering the distance between the disjunct populations at Pafuri and Leysdorp $(200 \mathrm{~km})$, seed dispersal by elephants over this distance should be highly unlikely as Bunney, Bond \& Henley (2017) reported a maximum seed dispersal distance by elephant of $65 \mathrm{~km}$. A most likely explanation would be that these two disjunct populations are the result of local extinction of intervening populations, or the intervening habitat being unsuitable. Elsewhere in Africa, B. aethiopum is characterised by such wide distributions, and similarly with high local abundance (Salako et al. 2018b).
The alternative view for the disjunction is that the palm is an introduced species (Dyer 1952), possibly as the area where the palms are found are situated along an ancient trade route (Figure 1) between Delagoa Bay (Maputo) and Zimbabwe (De Vaal 1984). Evidence exists that trade was taking place between Islamic traders and people from the Limpopo area as far back as the 8th century (Wood 2000) and various ancient smelters are known from the Gravelotte-TzaneenLeydsdorp region of the Murchison Range dating back to the 15th century (Miller et al. 2001). These activities would certainly have attracted traders from the north to trade cattle for iron, copper tools or artefacts (De Vaal 1985; Miller et al. 2001), which has been well reported for Mapungubwe along the Limpopo River, on the border with Zimbabwe (Prinsloo $\&$ Colomban 2008). The postulate is that seeds were discarded at this halfway mark (Figure 1).

It is also worth considering that Borassus seems to have a preference for alluvial areas with seasonal rainfall - they are often found on floodplains and in gallery forest - and these areas are also popular with farmers and as the location for human settlements. Therefore, it may be that Borassus and people share a habitat preference. Both cohabitation and the socio-economic value of the palm (Salako et al. 2018a) may be an explanation for current Borassus distributions; therefore, the interpretation of past historical plant movements based on current distributions is presented here with caution.

\section{Diagnostic characters}

Borassus aethiopum is geographically and ecologically separated from Jubaeopsis caffra and Raphia australis. Jubaeopsis caffra is found on sandstone cliffs and on the northern banks of the Msikaba and Mtentu rivers in Pondoland, while Raphia australis is restricted to the swampy forests of Maputaland. Borassus aethiopum can, however, be distinguished morphologically from J. caffra and R. australis in that the leaves of B. aethiopum are costa-palmate, while those of $J$. caffra and $R$. australis, and similarly for Phoenix reclinata, are pinnately compound. Hyphaene coriacea and $H$. petersiana also have costa-palmate leaves and can be distinguished from B. aethiopum in that the leaves of B. aethiopum are $3 \mathrm{~m}-4 \mathrm{~m}$ long, while those of Hyphaene species are $1.5 \mathrm{~m}-2.0 \mathrm{~m}$ long; and the fruit of B. aethiopum is $7 \mathrm{~cm}-17 \mathrm{~cm}$ in diameter, yellow to orange brown in colour and that of the Hyphaene species is $4 \mathrm{~cm}-5 \mathrm{~cm}$ in diameter and reddish brown in colour.

\section{Key to the native palms of South Africa}

1A. Leaves costa-palmate.............................................................

1B. Leaves pinnate ..................................................................

2A. Stem to $25 \mathrm{~m}$ tall; leaves $3 \mathrm{~m}-4 \mathrm{~m}$ long; fruit $7 \mathrm{~cm}-17 \mathrm{~cm}$ in diameter, yellow to orange brown when mature ..Borassus aethiopum

2B. Stem to $7 \mathrm{~m}$ tall; leaves $1.5 \mathrm{~m}-2.0 \mathrm{~m}$ long; fruits $4 \mathrm{~cm}-5 \mathrm{~cm}$ in diameter, reddish brown when mature ........3

3A. Fruit ovate to pear-shaped and ridged, with distinctly narrow base; stems up to $5 \mathrm{~m}$ tall; multi-stemmed; mainly a coastal distribution..................Hyphaene coriacea 
3B. Fruit globose-oblong, without ridges; stems up to $7 \mathrm{~m}$ tall; usually solitary; associated with the drier interior ..Hyphaene petersiana

4A. Single stemmed; leaves $6 \mathrm{~m}-10 \mathrm{~m}$ long, hooked spines on the margin of leaflets; fruit covered with overlapping scales..... Raphia australis

4B. Multi-stemmed; leaves less than $6 \mathrm{~m}$ long, margin of leaflet entire or crenulate; fruits smooth 5

5A. Petiole without spines; leaves up to $6 \mathrm{~m}$ long, silvery bluegreen at a distance, bright green nearby, pinna reduplicate, margin entire; monoecious; fruit round, $20 \mathrm{~mm}$ in diameter; restricted in distribution to northern banks of Msikaba and Mtentu rivers, Pondoland Jubaeopsis caffra

5B. Petiole with long, sharp spines at the base; leaves up to $4 \mathrm{~m}$ long, light to dark green, induplicately pinnate, margin minutely crenulate; dioecious; fruit ovate, $15 \mathrm{~mm}$ in diameter; widely distributed throughout tropical and subtropical Africa Phoenix reclinata

\section{Population description Vegetation}

In the Leydsdorp region, the populations are associated with other Lowveld tree species such as Albizia versicolor Welw. ex Oliv. (Fabaceae), Combretum collinum Fresen. (Combretaceae), Diospyros mespiliformis Hochst. ex. A.DC. (Ebenaceae), Peltophorum africanum Sond. (Fabaceae), Philenoptera violacea (Klotzsch) Schrire (Fabaceae), Sclerocarya birrea Hochst. (Anacardiaceae) and Trichilia emetica Vahl. (Meliaceae). Common shrubs include Dichrostachys cinerea (L.) Wight \& Arn. (Fabaceae), Flueggea virosa (Roxb. ex Willd.) Dalzell (Euphorbiaceae) and Phyllanthus reticulatus Poir. (Euphorbiaceae). Commonly encountered invasive aliens include Chromolaena odorata (L.) R.M.King \& H.Rob. (Asteraceae), Lantana camara L. (Verbenaceae), Melia azedarach L. (Meliaceae) and Thevetia peruviana K.Schum. (Apocynaceae). The palm typically forms groves (aggregates) within the vegetation (Salako et al. 2018a) and is not evenly distributed as part of the matrix as is the case with the other species mentioned above.

\section{Population structure}

A total of 614 plants were recorded in the Leydsdorp area (Table 1), of which $25 \%$ were sub-juveniles ( $<1 \mathrm{~m}$, no stem), $43 \%$ were juveniles (non-reproductive, with stem bearing leaf sheaths) and 32\% were adults (reproductive, stem with swelling; 1:1.3 male:female). The size-class distribution showed variation in the quotient (0.8-1.4; Figure 3), which is indicative of an unstable population (Siebert et al. 2018). The palm population is probably subjected to recruitment events

TABLE 1: Number of individuals per life stage as recorded for Borassus aethiopum in the Leydsdorp area during October 2016.

\begin{tabular}{lc}
\hline Life stage & Individuals \\
\hline Mature male & 86 \\
Mature female & 110 \\
Juveniles & 264 \\
Sub-juveniles & 154 \\
\hline Total & $\mathbf{6 1 4}$ \\
\hline
\end{tabular}

Note: The number of dead adults was 8. as a result of rainfall that coincide with fruit maturity and fall (Barot, Gignoux \& Menaut et al. 1999), which is reflected by the formation of groves of the same age.

The population has an SDI value slightly above 0.1 (i.e. 0.18 ), which reveals that size frequency is not steeper than what would be expected from an exponentially declining population. This is an indication that individuals are evenly distributed amongst the size classes, but this needs to be considered with PI values that are based on the assumption that an ideal undisturbed population should represent a monotonic decline $(\mathrm{PI}=0)$. This was, however, not typical for B. aethiopum (PI = 2), which has a discontinuous population, where larger individuals $(3.1 \mathrm{~m}-5.0 \mathrm{~m}$ tall) show a higher frequency than the previous size class. This could be explained by recruitment events as sub-adult and adult plants of the same size are often found in separate clumps creating patches of high local abundance (Salako et al. 2018b). Established sub-juveniles $(0.1 \mathrm{~m}-1.0 \mathrm{~m}$ tall) and juveniles $(1.1 \mathrm{~m}-3.0 \mathrm{~m}$ tall) were also not associated with these clumps and were found further away (Figure 2f). This is in accordance with the Barot et al. (1999) model that predicted distancedependent survival rates to explain these outward shifts because of extreme intraspecific competition between seedlings (Barot \& Gignoux 2003).

\section{Conclusion}

Borassus aethiopum is distinguishable from other South African palms based on stem, leaf and fruit characters and geographical distribution. It is one of three indigenous species with costa-palmate leaves. It can be confused with Hyphaene petersiana as both have a single stem containing a swelling. However, B. aethiopum can be distinguished by its larger leaves and fruit.

The occurrence of B. aethiopum in southern Zimbabwe makes its occurrence in South Africa logical. However, its association with the ancient trade routes that ran through South Africa and Zimbabwe will always cast doubt over its natural occurrence in both these countries. Borassus aethiopum is a tropical African palm, and regardlees of whether it was dispersed by humans or animals, it should be recognised as indigenous to the Granite Lowveld as the palms are part of

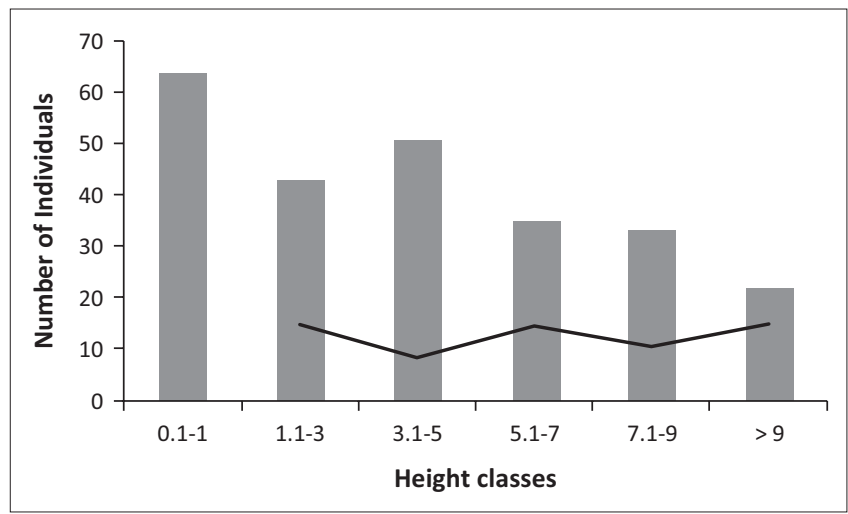

FIGURE 3: Height classes ( $\mathrm{m}$ ) and quotient analyses (solid black line) of Borassus aethiopum in the Leydsdorp area (Limpopo province). 
the natural vegetation and are characterised by a size-class distribution reflecting a stable population.

\section{Specimens examined}

SOUTH AFRICA. LIMPOPO. - 2231 (Messina): At the confluence of the Luvuhu and Limpopo rivers, Pafuri, (-DD), 12 April 2014, Zambatis \& Zambatis GZ1546 (KNP). - 2330 (Tzaneen): Road from Tzaneen to Leydsdorp, half way on right, Police Station, (-DC), October 1946, Kettlitz PRE36392 (PRE). - 2430 (Pilgrim's Rest): 7.5 miles southwest of Leydsdorp, (-AB), 5 November 1948, Codd \& Dyer 4701 (PRE); Leydsdorp, Farm Harmony, along edges of pivot field, (-AB), 31 October 2016, Cloete E Siebert 1 (PRE, PUC); Leydsdorp, T-junction of Ofcalaco-Gravelotte-Tzaneen roads, (-BA), 31 October 2016, Cloete E Siebert 2 (PRE, PUC).

\section{Acknowledgements}

Mr Hardus Cloete is thanked for his assistance with fieldwork. Mr Scott van Eden provided the distribution maps. Prof. Braam van Wyk and Dr Hugh Glen are thanked for valuable discussions on the topic and for providing locality data. The Pretoria National Herbarium and Skukuza Herbarium are acknowledged for providing access to study material. The key was tested by field botanists in South Africa.

\section{Competing interests}

The authors declare that they have no financial or personal relationships that may have inappropriately influenced them in writing this article.

\section{Authors' contributions}

S.J.S. planned and coordinated the study and wrote the article. M.S. contributed to the writing of the article and was responsible for the taxonomic treatment and construction of the key.

\section{Funding}

Funding for this study was provided by the North-West University.

\section{References}

Ali, A., Alhadji, D., Tchiegang, C. \& Saiuml, C., 2010, 'Physico-chemical properties of palmyra palm (Borassus aethiopum Mart.) fruits from Northern Cameroon' African Journal of Food Science 4(3), 115-119.

Barot, S. \& Gignoux, J., 2003, 'Neighbourhood analysis in the savanna palm Borassus aethiopum: Interplay of intraspecific competition and soil patchiness', Journal of Vegetation Science 14(1), 79-88. https://doi.org/10.1658/1100-9233(2003)014 [0079:NAITSP]2.0.CO;2

Barot, S., Gignoux, J. \& Menaut, J.C., 1999, 'Seed shadows, survival and recruitment: How simple mechanisms lead to dynamics of population recruitment curves', Oikos 86(2), 320-330. https://doi.org/10.2307/3546449

Barot, S., Gignoux, J., Vuattoux, R. \& Legendre, S., 2000, 'Demography of a savanna palm tree in Ivory Coast (Lamto): Population persistence and life-history', Journa of Tropical Ecology 16(5), 637-655. https://doi.org/10.2307/3546449

Bayton, R.P., 2007, 'A revision of Borassus L. (Arecaceae)', Kew Bulletin 62(4), 561-585.

Beccari, O., 1914, 'Studio sui Borassus e descrizione di un genere nuovo asiatico di Borasseae', Webbia 4, 293-385. https://doi.org/10.1080/00837792.1914.10669572
Bunney, K., Bond, W.J. \& Henley, M., 2017, 'Seed dispersal kernel of the largest surviving megaherbivore - the African savanna elephant', Biotropica 49(3), 395-401. https://doi.org/10.1111/btp.12423

Coates Palgrave, K., 2002, Trees of southern Africa, Struik, Cape Town, p. 1212.

Dalziel, J.M., 1937, The useful plants of West Tropical Africa, The Crown Agents for the Colonies, London, p. 496.

De Vaal, J.B., 1984, 'Old trading footpaths and wagon roads in the Eastern and Northern Transvaal', Contree 16, 5-15.

De Vaal, J.B., 1985, 'Trade along the oldest routes', Contree 17, 5-14.

Dransfield, J., 2010, 'Arecaceae (Palmae)', Flora Zambesiaca 13(2), 35-69.

Dyer, R.A., 1952, 'A note on the distribution of the palms of South Africa with special reference to Borassus in the Transvaal', South African Journal of Science 48 215-220.

Esterhuyse, N., Von Breitenbach, J. \& Sohnge, H., 2001, Remarkable trees of South Africa, Briza, Pretoria, p. 202.

Glen, H.F., 2002, Cultivated plants of southern Africa, Jacana, Johannesburg, p. 428.

Hurter, P.J.H., Von Staden, L., Victor, J.E. \& Van Wyk, A.E., 2007, Jubaeopsis caffra Becc., National assessment: Red list of South African plants, version 2017.1, viewed 21 November 2017, from http://redlist.sanbi.org/species.php?species= 3416 -

Hutchinson, J. \& Dalziel, J.M., 1936, Flora of West Tropical Africa, vol. 2, Crown Agents for the Colonies, London, p. 544

Jumelle, H.L. \& Perrier de la Bâthie, H., 1913, 'Palmiers de Madagascar', Annales du Musée Colonial de Marseille sér 3.1, 1-91.

Klopper, R.R., Chatelain, C., Bänninger, V., Habashi, C., Steyn, H.M., De Wet, B.C. et al. 2006, Checklist of the flowering plants of sub-Saharan Africa. An index of accepted names and synonyms, Southern African Botanical Diversity Network Report No. 42, SABONET, Pretoria, p. 894.

Martius, C.F.P.von., 1838, Historia naturalis palmarum, vol. 3, T.O. Weigel, Leipzig, p. 568.

Matimele, H.A., Massingue, A.O., Raimondo, D., Bandeira, S., Burrows, J.E., Darbyshire, I. et al., 2016, Raphia australis, IUCN Red list of threatened species 2016, viewed 04 October 2018, from https://doi.org/10.2305/IUCN.UK.2016-3.RLTS.T30359A8 5955288.en

Miller, D., Killick, D. \& Van Der Merwe, N.J., 2001, 'Metal working in the Northern Lowveld, South Africa AD 1000-1890', Journal of Field Archaeology 28(3-4), 401-417. https://doi.org/10.1179/jfa.2001.28.3-4.401

Mucina, L. \& Rutherford, M.C., 2006, The vegetation of South Africa, Lesotho and Swaziland, Strelitzia 19, SANBI, Pretoria, p. 807.

Orwa, C., Mutua, A., Kindt, R., Jamnadass, R. \& Anthony, S., 2009, Agroforestree Database: A tree reference and selection guide, version 4.0, viewed 01 March 2018, from http://www.worldagroforestry.org/sites/treedbs/treedatabases.asp

Prinsloo, L.C. \& Colomban, P., 2008, 'A Raman spectroscopic study of the Mapungubwe oblates: Glass trade beads excavated at an iron age archaeological site in South Africa', Journal of Raman Spectroscopy 39(1), 79-90. https://doi.org/10.1002/ jrs.1816

Salako, V.K., Kénou, C., Dainou, K., Assogbadjo, A.E. \& Kakaï, R.G., 2018a, 'Impacts of land use types on spatial patterns and neighbourhood distance of the agroforestry palm Borassus aethiopum Mart. in two climatic regions in Benin, West Africa, Agroforestry Systems February, 1-15. https://doi.org/10.1007/s10457-0180205-y

Salako, V.K., Vihotogbé, R., Houéhanou, T., Sodé, I.A. \& Kakaï, R.G., 2018b, 'Predicting the potential impact of climate change on the declining agroforestry species Borassus aethiopum Mart. in Benin: A mixture of geostatistical and SDM approach', Agroforestry Systems June, 1-18. https://doi.org/10.1007/s10457$018-0262-2$

Scott, D.W., 2009, 'Sturge's rule', Wiley Interdisciplinary Reviews: Computationa Statistics 1(3), 303-306. https://doi.org/10.1002/wics.35

Schmidt, E., Lotter, M. \& McCleland, W., 2007, Trees and shrubs of Mpumalanga and the Kruger National Park, Jacana, Johannesburg, p. 702.

Siebert, S.J., Struwig, M., Knoetze, L. \& Komape, D.M., 2018, 'Celtis sinensis Pers, (Ulmaceae) naturalised in northern South Africa and keys to distinguish between Celtis species commonly cultivated in urban environments', Bothalia 48, a2288. https://doi.org/10.4102/abc.v48i1.2288

Siebert, S.J., Zobolo, A.M. \& Dowe, J.L., 2010, 'Livistona chinensis, a first record of a naturalized palm in South Africa', Bothalia 40, 55-102.

Van Wyk, A.E. \& Smith, G.F., 2001, Regions of floristic endemism in southern Africa: A review with emphasis on succulents, Umdaus Press, Hatfield, p. 199.

Warburg, O., 1895, 'Die Palmen Ostafrikas und ihre Verwerthung', in H.G.A. Engle (ed.), Pflanzenwelt Ost-Afrikas und der Nachbargebiete, Theil B, Die Nutzpflanzen Ost-Afrikas, p. 27, Dietrich Reimer Verlag, Berlin.

Wicht, H., 1969, The indigenous palms of southern Africa, Cape Town, Citadel Press, p. 62.

Wood, M. 2000 'Making connections: Relationships between international trade and glass beads from the Shashe-Limpopo area', Goodwin Series 8, 78-90.

Wright, C.H., 1897, 'Palmae', in W.T. Thiselton-Dryer (ed.), Flora capensis: Being a systematic description of the plants of the Cape colony, Caffraria, \& Port Natal (and neighbouring territories), vol. 7, pp. 28-30, Haemodoraceae to Liliaceae, Reeves and Co., Kent.

Zona, S. \& Henderson, A., 1989, 'A review of animal-mediated seed dispersal of palms', Selbyana $11,6-21$. 